ppi $201502 Z U 4645$

Esta publicación cientifica en formato digital es continuidad de la revista impresa ISSN-Versión Impresa 0798-1406 / ISSN-Versión on line 2542-3185Depósito legal pp

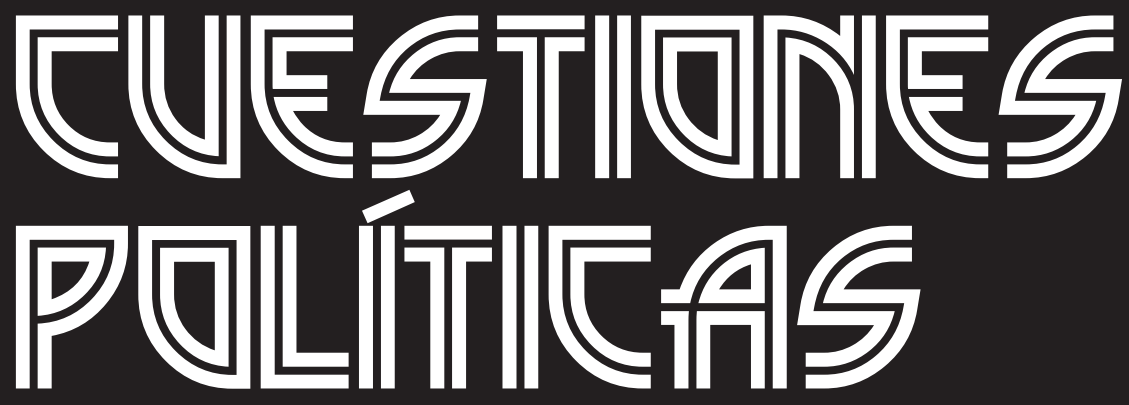

Instituto de Estudios Políticos y Derecho Público "Dr. Humberto J. La Roche' de la Facultad de Ciencias Jurídicas y Políticas de la Universidad del Zulia Maracaibo, Venezuela
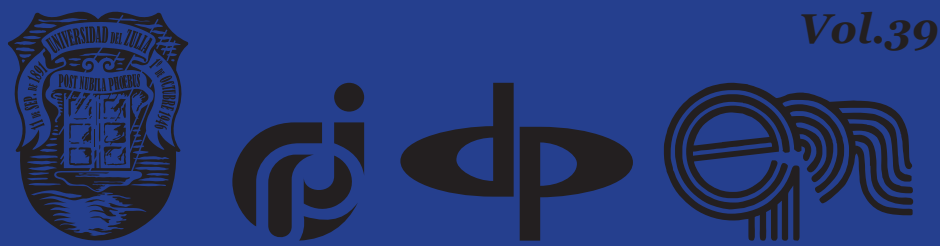


\title{
Juvenile Justitia and the protection of children's rights in Europe: the practice of the European Court of Human Rights
}

\author{
DOI: https://doi.org/10.46398/cuestpol.3968.09
}

\author{
Mykola Bondaruk * \\ Serhiy H. Melenko ** \\ Liubov Omelchuk *** \\ Liliya Radchenko **** \\ Anzhela Levenets $* * * * *$
}

\section{Abstract}

The objective of the research is to analyze the main violations of children's rights within the European Convention on Human Rights to highlight the basic positions of the European Court of Human Rights ECHR on their protection, as well as to determine the advisability of applying the practice of this court by the European states. The methodological basis of the work consists of different methods, such as analysis and synthesis, dialectical, logical-legal and formal-legal. The result of this work allowed identifying the role of the decisions of the European Court of Human Rights as a source of European law and its importance for the protection of the rights of the child, interpreting the legal positions established in the pertinent decisions of the said court and comparing them, to justify the need for your careful observation of the practice of the ECHR in the application of the law. It is concluded that the practice of the ECHR is recognized as a source of law in most states. And although the Ukrainian legal tradition does not recognize the status of judicial precedent as a source of law, such precedents are actively used in everyday legal activity.

* Doctor of Legal Sciences, Associate Professor, Honored Worker of Education of Ukraine, Professor of the Department of Private Law, Yuriy Fedkovych Chernivtsi National University. ORCID ID: https:// orcid.org/oooo-0oo1-7386-465X. Email: m.bodnaruk@chnu.edu.ua

** Doctor of Juridical Sciences, Full Professor, Department of European Law and Comparative Law Studies, Yuriy Fedkovych National University of Chernivtsi, Ukraine. ORCID ID: https://orcid. org/oooo-0oo2-3912-548X. Email: s.melenko@chnu.edu.ua

*** Ph.D. in Law, Associate Professor, Associate Professor of Department of Criminalistics and Criminal Process, University of the State Fiscal Service of Ukraine. ORCID ID: https://orcid.org/oooo-0oo22457-0118. Email: o.l.v.0328@gmail.com

**** Ph. D. in Law, Associate Professor; Associate Professor of Civil Law, Institute of Law, Taras Shevchenko National University of Kyiv. ORCID ID: https://orcid.org/oooo-0002-3783-9489. Email: gli@online. ua

$* * * *$ Ph. D. in Law, Associate Professor of the Department of Constitutional Law and Justice, Odessa I. I. Mechnikov National University. ORCID ID: https://orcid.org/oooo-0002-1941-513X. Email: Angel1lev@onu.edu.ua 
Mykola Bondaruk, Serhiy H. Melenko, Liubov Omelchuk, Liliya Radchenko y Anzhela Levenets

Keywords: youth policy; European Court of Human Rights; European Convention on Human Rights; Convention on the Rights of the Child; legal reality of Ukraine.

\section{Justicia juvenil y protección de los derechos del niño en Europa: la práctica del tribunal europeo de derechos humanos}

\section{Resumen}

La investigación tiene como objetivo analizar las principales violaciones de los derechos del niño dentro del Convenio Europeo de Derechos Humanos para resaltar las posiciones básicas del Tribunal europeo de Derechos Humanos TEDH sobre su protección, así como determinar la conveniencia de la aplicación de la práctica de este tribunal por parte de los estados europeos. La base metodológica del trabajo consta de diferentes métodos, como análisis y síntesis, dialéctico, lógico-legal y formal-legal. El resultado de este trabajo permitió identificar el papel de las decisiones del Tribunal europeo de Derechos Humanos como fuente del derecho europeo y su importancia para la protección de los derechos del niño, interpretar las posiciones legales establecidas en las decisiones pertinentes del referido tribunal y compararlas, para justificar la necesidad de su observación cuidadosa de la práctica del TEDH en la aplicación de la ley. Se concluye que la práctica del TEDH se reconoce como fuente de derecho en la mayoría de los estados. Y aunque la tradición jurídica ucraniana no reconoce la condición de precedente judicial como fuente de derecho, tales precedentes se utilizan activamente en la actividad jurídica cotidiana.

Palabras clave: política juvenil; Tribunal Europeo de Derechos Humanos; Convenio Europeo de Derechos Humanos; Convención sobre los Derechos del Niño; realidad jurídica de Ucrania.

\section{Introduction}

In today's democratic society, the protection of human rights is one of the most pressing issues. A set of relevant principles was formulated by European thinkers of the Enlightenment in the eighteenth century: humanism, education, equality of all members of society (Shyshka and Tkalych, 2020). The pace of development of society, the growth of quantitative and qualitative human needs has led to an increase in the 
types of human rights violations, as well as the backlog of legal regulation of relations arising from such violations. This problem is even more acute in the protection of violated rights of the child, as it can be attributed to more vulnerable social groups, and in practice manifests itself in gaps in legal regulation or unequal interpretation of the law on the rights of the child. Accordingly, modern private law must be transformed and improved to be able to meet the challenges of modernity (Tkalych et al., 2020).

A partial solution to this problem can be considered the European Court of Human Rights (ECtHR), which at the international level guarantees the observance of human rights, including the child, their protection from the violation, or any other encroachment.

Paragraph 1 of the Law of Ukraine "On Ratification of the Convention for the Protection of Human Rights and Fundamental Freedoms of 1950, the First Protocol and Protocols No. 2, 4, 7 and 11 to the Convention" (1997) (Law 475/97-VR /1997 of July 30), in particular, fully recognizes Article 46 of the Convention fundamental human freedoms of 1950 to recognize the jurisdiction of the European Court of Human Rights in all matters concerning the interpretation and application of the Convention as binding and without the conclusion of a special agreement. Ukraine is moving towards the harmonization of its legislation with the legal framework and the recommended EU standards (Pavlova et al., 2020).

Thus, in recognizing the jurisdiction of the ECtHR, Ukraine has made an unspoken obligation to follow the provisions set out in its decision, which in turn serve as a source of law and are a reference point for legal decisions, in proceedings concerning the rights and interests of minors (children). Other European countries have made the same commitment.

The object of the study is the relationship concerning the protection of children's rights, which is considered through the prism of the decisions of the ECtHR. The subject of research is juvenile justice and its significance in the context of ECtHR decisions.

\section{Methodology of the study}

The methodological basis of the work was both general and special methods, including analysis and synthesis, dialectical, logical-legal, and formal-legal.

Firstly, the synthesis method, as a rule, complements the method of analysis and allows you to summarize the results obtained by studying the separate elements of a particular phenomenon using the method of analysis (Kharytonov et al., 2021). The analysis and synthesis made it possible to comprehensively describe and characterize the essence of juvenile justice through the prism of ECtHR decisions on the protection of children's rights, 
Mykola Bondaruk, Serhiy H. Melenko, Liubov Omelchuk, Liliya Radchenko y Anzhela Levenets 170

Juvenile Justitia and the protection of children's rights in Europe: the practice of the European

to identify and compare basic positions on the legal regulation of relations related to violations of children's rights. The synthesis also served as a basis for combining original ideas, principles, developments for further effective use of the legal positions of the ECtHR in the development and formation of juvenile justice.

Moreover, the dialectical method revealed the general features, connections, and patterns that arise in the protection of the rights of the child of the ECtHR.

Furthermore, the formal-legal method helped to clarify the essence and content of legal norms, their functions, features of the concepts they define, and the processes they regulate, within the research topic, and the hermeneutic method allowed to study the content of certain legal norms and theoretical provisions in the context of topical issues of juvenile justice based on acquaintance with the texts of normative and doctrinal sources.

Also, the use of the formal-dogmatic method made it possible to reveal the phenomenon of children's rights by covering these rights in the norms enshrined in international legal acts, as well as to determine that these rights must be ensured in compliance with the principle of the best interests of the child.

The axiological method served as a basis for substantiating the value of children's rights and the importance of their observance for the formation of juvenile justice.

Thanks to the comparative law method, it has become possible to compare the main legal positions of the ECtHR, considering the specifics of each case.

The special legal method was used in assessing the effectiveness of the ECtHR's activities to protect the rights of the child and the appropriateness of using the legal precedents of the ECtHR to develop and establish a national system of juvenile justice.

The logical-legal method helped formulate proposals for the use of ECtHR practice in the formation and development of juvenile justice.

Finally, generalization, as a method, made it possible to identify the main problems and vectors of development of the application of ECtHR decisions in the formation of juvenile justice.

\section{Analysis of recent research}

Many works by domestic and foreign scientists are devoted to the study of issues related to the research topic. 
Thus, Opatsky (2012) studied the juvenile policy of the state through the prism of the direction of the activities of the respective subjects, which is the basis for the formation of juvenile justice as one of the means of ensuring the rights and freedoms of children. The author identified the reason for the problematic development of juvenile policy and the slow pace of its pace in the specifics of the historical path of juvenile justice in Ukraine. The scholar also defined the goal of the state's juvenile policy, which can be fully compared with the goals of the ECtHR's activities to protect the rights of the child.

The study by Mendzhul (2020) reveals the meaning and essence of the principle of the best interests of children in the practice of the ECtHR and emphasizes that this principle should be predominant in decision-making by both international courts and national courts. Thus, the author found that the ECtHR uses this principle in various situations, when considering cases of paternity, family reunification, the relationship between the adopter and the adopted child, contact with the child, and the right to communicate with him of the parents who lives separately, or other relatives, deprivation of parental rights, etc.

Krestovskaya (2008) made a significant contribution to understanding the essence of the concept of juvenile justice. The scholar's works examine in detail the paternalistic, protectionist, and autonomist doctrines of juvenile law and their combination in the Ukrainian legal system. Much attention has been paid to the existence of juvenile law as a separate branch, its principles, functions, system, and connection with morality, religion, and politics.

The works of Mamych (2012) analyzed the practice of the ECtHR to protect the rights of children, from mental and physical violence, resulting in the conclusion that children have the same rights as adults to demand from society and the state respect for honor and dignity, protection from violence, enslavement, and exploitation.

It is worth mention, that Dzhuzha's (2013) research is aimed at identifying the main legal mechanisms for detecting and preventing crimes against the sexual integrity of a child, on the example of ECtHR decisions.

In turn, Volkova (2018) focused on the practice of the ECtHR in cases concerning Ukraine and analyzed its impact on the adoption of decisions on the child by national courts. Her work describes certain decisions of the ECtHR in various categories of cases concerning the protection of the rights and interests of the child and concludes that the child is a subject of international law, so the ECtHR and national courts have the right to apply international law rights and interests of the child, even if such acts of children are not directly related. 
Given the achievements of scholars and practitioners in addressing these issues, further need to study the problem of forming a generally accepted definition of "juvenile justice", the balance of the best interests of the child and privacy, the relationship between propaganda in ECtHR decisions to maintain parental contact with children in custody and to maintain the normal psychological state of the child, which may be disturbed by the return of the child in custody to biological parents, and the expediency of using ECtHR legal positions by national courts and other bodies directly or indirectly involved in the formation of juvenile justice.

\section{Results and discussion}

One of the main tasks of every modern democratic and civil state is the protection and defense of human rights. Given that children, due to the extent of their legal capacity, may not always be able to independently violate their freedoms and rights, ie use state protection mechanisms, and their representatives may ignore the obligation to protect children's rights, ensuring the rights of the child deserves special attention from the state both at the national and international levels.

To ensure the above objectives, the state pursues a juvenile policy, which can be defined as part of domestic policy, a special type of social activity governed by international and national law, aimed at effectively ensuring the rights and legitimate interests of minors (Opatsky, 2012).

The juvenile policy should include provisions for the construction of mechanisms and a system of juvenile justice, which is designed to protect the rights and interests of minors in court.

There is currently no consensus among theorists and practitioners on the interpretation of juvenile justice. The most successful, according to the author, is the interpretation of Krestovskaya, according to which juvenile justice is a system of state, municipal, and public, judicial, law enforcement and human rights bodies, institutions, and organizations that based on juvenile law and with the help of medical, social and psychologicalpedagogical methods administer justice, prevention and prevention offenses against and against children, protection of rights, freedoms, and interests, as well as re-socialization of children in difficult life situations (Krestovskaya, 2008).

Ukraine, in particular equal to the developed countries of Europe, has also taken certain steps towards the introduction of juvenile justice, as evidenced by the Decree of the President of Ukraine "On the Concept of Criminal Justice for Juveniles" (Decree 597/2011 of May 24,), the Order of the Cabinet of Ministers of Ukraine "On approval of the action plan for the implementation of the Concept of development of criminal justice for 
minors in Ukraine" (Order 1039-p /2011 of February 8), as well as the separation in a separate chapter of the Criminal Procedure Code of Ukraine (Law 4651-VI/2012 of April 13) provisions for the conduct of proceedings against minors. At the same time, juvenile justice aims not only to prosecute or re-educate child offenders but also to address other problems of children, those related to the violation of their rights, including those arising from civil, family, or other legal relations.

In view of the above, it can be concluded that juvenile justice institutions in Ukraine are generally developing at a slow pace and rather one-sidedly, ie only within the framework of criminal proceedings against minors, while other offenses committed by third parties against minors are ignored, which entails the inability to create an effective mechanism to protect the rights of children, taking into account their special legal status.

Instead, the protection of children's rights at the level of substantive international law is ensured by the European Convention for the Protection of Human Rights and Fundamental Freedoms (1950) (hereinafter - the European Convention) and the Convention on the Rights of the Child (1989), developed by the United Nations. At first glance, the Convention on the Rights of the Child is more personal and special, as it specifically concerns the rights of the child. In particular, the above convention stipulates:

- inalienable right to life (Article 6).

- mandatory registration of the child after birth (Article 7).

- ensuring the individuality of the child (Article 8).

- the right to free expression of views (Article 12) and opinions (Article 13).

- the child's right to freedom of thought, conscience, and religion (Article 14).

- protection of the child from all forms of physical and psychological violence, insults or abuse, lack of care or careless and brutal treatment and exploitation through the necessary legislative, administrative, social, and educational measures (Article 14).

- the right of every child to a standard of living necessary for the physical, mental, spiritual, moral, and social development of the child (Article 19).

- the child's right to education (Article 28).

- the child's right to rest and leisure, the right to participate in games and entertainment activities appropriate to his age, and to freely participate in cultural life and engage in the arts (Article 31). 
174 Juvenile Justitia and the protection of children's rights in Europe: the practice of the European

- the child's right to protection from economic exploitation and the performance of any work (Article 32), etc.

From a practical point of view, the European Convention has a greater impact and significance, as it is the material basis of the work of the ECtHR, which in turn within the European Convention is to protect the rights of the child.

At the same time, the ECtHR refers in its decisions not only to the European Convention but also to the UN Convention on the Rights of the Child, thus symbolizing the unity of the principles of establishing guarantees for the protection of the rights of the child. Thus, in the decision A. v. The United Kingdom (23 September 1998) ECtHR mentions Art. 37 and Art. 19 of the UN Convention on the Rights of the Child, which urges States to protect children in the care of parents or others from "all forms of physical and mental violence, including sexual acts". In this judgment, the Court unequivocally points to the State's responsibility to protect children from domestic violence and elsewhere. Thus, the state's disregard for the problems of violence against children in the family or in other private institutions, failure to take appropriate measures to prevent it is seen as a concession to such actions by the state and as a violation of international legal obligations to protect children from torture and other cruel, inhuman, or degrading treatment or punishment (Dzhuzha, 2013).

Thus, the ECtHR can also be considered the highest institution of juvenile justice. In this regard, the states that have signed the European Convention are obliged to strictly follow the positions set out in the decisions of this institution.

According to the author, this commitment is the embodiment of unity, the cohesion of European states around the standards of human rights, including the child. At the inter-European level, the idea of creating a European Civil Code or another act that would extend to European countries has long been nurtured. This idea has not only positive sides but also negative ones, which are primarily related to the problem of ensuring the preservation of the identity of national legislation because the basis of any legal system is legal awareness, which in turn is closely linked to mentality, genesis and the philosophy of law that is inherent in each state.

In this case, the case-law of the ECtHR is a common source of law for European countries, which complements the provisions of the European Convention as a source of law in the form of an international treaty, thus closing gaps in the legal regulation of human rights, including children, each European state.

The practice of the ECtHR as a source of legal influence has the following characteristics: 
1) serves as a basis for the actual functioning of the European Convention.

2) is personified in a set of legal positions through which there is a legal influence.

3) exerts informational, psychological, educational, law enforcement, social and regulatory influence on the consciousness and behavior of legal entities.

4) ensures the formation of legal awareness within the framework of human rights.

5) gives rise to legal consequences in case of violation of the articles of the European Convention.

Since the powers and jurisdiction of the ECtHR are unparalleled in the world, a large number of applications are received annually by this court, but complaints concerning violations of children's rights belong to the first category of complaints under the priority policy of the ECtHR (Mamych, 2012). That is, the protection of the rights of the child is a priority over the protection of the rights of other adults. Everyone has equal rights, including the same right to protection, but due to the significant vulnerability of minors, the lack of enhanced guarantees from states to respect their rights at the national level, the ECtHR pursues a chosen policy of priority and recognizes the interests of children.

It should be noted that, unlike the laws of many European countries, the ECtHR does not link the possibility of directly seeking protection with the capacity of a person, ie the applicant may be minors themselves. Nachova v Bulgaria (2005) highlighted a different approach to marginalization and discrimination (applicants belonged to the Roma or Roma ethnic group) and acknowledged the lack of age as a criterion for admissibility of the complaint (the applicant was 3 years old at the time of the complaint). However, in cases in which the applicants are the child's legal representatives, there are many more cases in the ECtHR's practice.

Thus, about the general situation of children's access to justice in 2017, the Child Rights International Network (CRIN) examined how the legal systems of 197 countries allow children to exercise their rights or, conversely, provoke violations that they must fight. In the Global Report on Children's Access to Justice prepared by this organization, Ukraine received 55.4 points and together with Rwanda took 8oth place (Pavlichenko and Martynenko, 2017).

According to the author, analyzing the case-law of the European Court of Human Rights on the protection of children's rights, first, it is worth emphasizing the decision of the ECtHR in the case of Marckx v. Belgium (13 de junio de 1979, 1979). Moreover, although the ECtHR considered 
Mykola Bondaruk, Serhiy H. Melenko, Liubov Omelchuk, Liliya Radchenko y Anzhela Levenets 176

Juvenile Justitia and the protection of children's rights in Europe: the practice of the European

this case back in 1979, it should be considered a textbook and one of the fundamental, because in the decision, in this case, the ECtHR equated the rights of children born in wedlock and illegitimate children. Thus, the applicant relied on the fact that the State had established a complicated procedure for establishing legal relations between mother and child in the event of the birth of a child out of wedlock.

As this procedure consisted of the recognition of the child and his / her subsequent adoption, the child did not have any legally established ties at all during this time, which violated his / her rights. In its decision, the ECtHR stated that if the state, within the framework of its domestic legal system, determines the regime of certain family relations, it must act thoughtfully so that the persons concerned could have a normal family life. Besides, the existence of legal guarantees in domestic law that would allow a child to be integrated into the family from birth was made mandatory. The ECtHR also noted that if the state aims to create conditions for the normal development of family relations between an unmarried mother and her child, then the state should not allow any discrimination on the grounds of birth.

And although in most European countries there are currently no restrictions based on the birth of a child in a formal marriage or not, the analyzed decision of the ECtHR is an example of the impact of the ECtHR's positions on the legislative and law enforcement activities of states.

The ECtHR is subject to various cases of violation of the rights of the child within the provisions of the European Convention, and one common feature of such consideration is the ECtHR's adherence to the principle of establishing the best interests of the child in each case. Thus, the scope of the concept of "best interests of the child" covers administrative. For example:

- appeals against decisions of guardianship authorities on determining how to participate in the upbringing of a child of one parent; decisions to consent to the alienation of property.

- decisions to establish the child's residence; the obligation of the subject of authority to take certain actions, namely, to amend the birth certificate of the child, etc.) and civil (in particular, cases of determining the child's place of residence.

- adoption.

- deprivation of parental affairs; establishment of guardianship and custody, and;

- recovery alimony and so on) litigation, the implementation of family law (Klim, 2014).

Indicative in the context of this is the decision M.S. v. Ukraine (11 October 2017), in which the ECtHR emphasized that, in establishing the best interests of the child, it is important to remember: 
1) it is in the best interests of the child to maintain his or her ties to the family unless it is proven that the family is unfit or manifestly dysfunctional.

2) in the best interests of the child to ensure its development in a safe, reliable, and stable environment that is not dysfunctional.

However, the interests of the child often do not coincide with the interests of the parents, and the interest of the child in such cases is predominant. This is confirmed by the judgment in Hunt v. Ukraine (7 March, 2006), in which the ECtHR emphasized that there must be a fair balance between the interests of the child and the interests of the parents, and, in striking such a balance, special attention must be paid to the most important interests of the child, which by their nature and importance must prevail over the interests of the parents.

Thus, in the decision in the case Haase v. Germany (08 July, 2004), the ECtHR noted that in the case of a child separated from his parents for a long time and under the care of a new family, maintaining the child's normal psychological state, which may be disturbed by new changes in his family environment, is a more important factor than the interest of parents in the return of the child.

At the same time, the ECtHR in some decisions insists on the need to maintain contact between parents and children in foster care, as any restriction on communication must be justified by grounds directly related to the circumstances of the case and the protection of the rights of such children. The ECtHR emphasizes that in such cases the balance between the restrictions and the purposes for which the restrictions were imposed is particularly important. Thus, in Andersson v. Sweden (14 October, 2004), the applicants (mother and son) challenged the ban on their personal meetings, communication by post or telephone. Although the reason for such a restriction was reasonable reason to believe that the son would try to flee the custody after contact with the mother, which was contrary to the interests of the child, the ECtHR found the reason to be disproportionate and found a violation of the European Convention.

In continuation of this position of the ECtHR, namely the communication of the child with his parents, it is worth paying attention to the decision in the case of Vyshnyakov v. Ukraine (24 October, 2018), which was considered in connection with the mother's improper execution of the court's decision to see the child. Thus, the ECtHR found that the improper implementation of the relevant court decision was the result of insufficiently developed legislative and administrative mechanisms that could accelerate the voluntary compliance with the agreements with the involvement of specialists in the service of children and families. In addition, the existing legislative and administrative mechanisms did not provide for appropriate 
Mykola Bondaruk, Serhiy H. Melenko, Liubov Omelchuk, Liliya Radchenko y Anzhela Levenets 178

Juvenile Justitia and the protection of children's rights in Europe: the practice of the European Court of Human Rights

and specific measures to enforce the decision to set up appointments following the principle of proportionality.

Besides, the main thesis of the decision Amanalachioai v. Romania (26 May, 2009) is that the interests of children require that family ties be broken only in particularly exceptional circumstances and that all measures should be taken to preserve personal ties and, if necessary, to rebuild the family. In this case, the ECtHR also noted: "the fact that the child could have been placed in a more favorable environment for his upbringing does not in itself justify his removal from the custody of his biological parents." However, in this case, it should be noted that the circumstances of this case concerned the removal of the child from the parents and his placement in the appropriate institution, ie no family ties between the child and another family were established.

Many questions are raised by the above statement as to which circumstances are "particularly exceptional", as the list of such circumstances, or at least the criteria by which such circumstances can be determined and established, is not provided by any legal act. Instead, the case-law of the ECtHR contains some developments in this regard, which will allow to draw parallels between situations and compare the relevant circumstances. Thus, the case of Saviny v. Ukraine (18 March, 2009) concerned the deprivation of a child from parents and deprivation of their parental rights because the parents were blind from birth, which in the opinion of the competent state body meant their inability to provide children with proper food, clothing, sanitation and to take care of children's health and to ensure their social adaptation. The ECtHR criticized this position and recognized the state as violating Art. 8 of the European Convention on deprivation of Sava's parental rights.

Violations of this article, which states that the right to respect for private and family life, are often established by the ECtHR. itself within the framework of interference in family life. Such cases within the framework of "family life" concern the protection of the rights of parents, but in any case, also affect the rights of the child, as the decision is made in full and comprehensive clarification of the circumstances considering the interests of the child. Thus, violation of Art. 8 of the European Convention is found in the decisions of the ECtHR on:

- establishment of paternity (Rasmussen v. Denmark, 28 November 1984, § 87, § 33 and Keegan v. Ireland, 26 May 1994, Series A § 290, $\S 45)$.

- deprivation of parental rights (decision in the case of the "Khanty of Ukraine" of December 7, 2006, application No. 31111/04).

- removal of the child (Savin v. Ukraine judgment of 18 December 2008, application No. 39948/06), and; 
- determination of the child's place of residence (ME v. Ukraine). [1, 85-86].

According to the authors, the practice of the ECtHR in cases where the interests of children are concerned is somewhat ambiguous and at first glance contradictory. For example, the ECtHR seeks to establish and maintain family ties between a child and his or her biological parents, while in some precedents the ECtHR deviates from its position and favors others, in the court's view, more important factors.

For example, the case of Kautzor v. Germany (24 September, 2012) concerns the establishment of paternity of the applicant in respect of the daughter, who after the divorce remained living with the mother and her new husband, who legally recognized his paternity with the applicant's daughter. By bringing an action before the domestic court, the applicant was denied leave of claim because the child already had a legal father. The ECtHR, considering Kautzor's application, also did not recognize the state's violation of Art. 8 and Art. 14 of the European Convention, referring to the fact that European law does not provide for the possibility of establishing biological paternity without first challenging the paternity of another man. At the same time, this decision once again forms a position concerning which European states are obliged to resolve the issue of compliance of the establishment of biological paternity with the best interests of the child.

It should be noted that the practice of the ECtHR on the establishment of paternity is of particular importance for European states not only as a source of substantive law but also procedural law. Thus, according to the author, in the decision of Kalacheva v. Russia (7 August, 2009), established the priority and importance of DNA examination as one of the most important evidence in this category of cases, as DNA analysis is recognized as the only scientific method of accurate paternity; its probative value significantly exceeds any other evidence presented by the parties to confirm or refute their close relationship.

The ECtHR also considers other cases of violation of the rights of the child granted to it by the European Convention as a person.

Thus, practice shows that the ECtHR actively protects children's rights to education and freedom of conscience. Thus, the applicant in Folgero and Others v. Norway (29 June, 2007) challenged in the ECtHR the refusal to exempt his children from school subjects in Christianity, religion, and philosophy. In the decision, in this case, the ECtHR insists on the violation by the state of Art. 2 of Protocol No. 1 to the European Convention proclaiming the right to education, as the respondent State has not provided adequate conditions for the provision of information and knowledge within the curriculum objectively, critically, and pluralistically. The ECtHR came to this conclusion based on a significant predominance 
of Christian themes and motives during study, which the applicant had requested to attend in the interests of his children. The ECtHR also noted that the state is prohibited from having an ideological influence on children, which be disrespect for the religious and philosophical beliefs of parents.

The decision in the case of Hasan Eylem Zengin v. Turkey (2008) is similar in meaning and significance.

Admittedly, even in today's civilized and tolerant society, given that minors are often influenced by adults, sometimes due to their physical weakness and inability to fight back, children still suffer from abuse by adults, usually people close to them: parents, relatives, etc. Examples of such situations abound in the practice of the European Court of Human Rights, which always recognizes the violation of Art. 3 of the European Convention.

Thus, the ECtHR found that the State had violated the above-mentioned Article and Article 13 of the European Convention in E and Others v. The United Kingdom (15 January, 2003) because the negligent attitude of social services had prevented years of abuse of children who because of such abuse received serious post-traumatic mental disorders.

The case of Kontrov v. Slovakia (24 September, 2007) differs from other categories of ECtHR cases concerning the protection of children's rights. According to the case file, on 2 November 2002, the applicant requested the relevant public authority to institute criminal proceedings against her husband for the ill-treatment of her. The applicant later withdrew her application under pressure from her husband and with the assistance of the police. In December of that year, her husband shot their joint minor daughter and son. Although the application to the ECtHR was filed by Kontrova regarding the non-payment of compensation due to her, considering the case of the ECtHR, it was recognized not only as a violation of Art. 13 of the European Convention (the right to an effective method of protection) due to lack of cash benefits to the mother, as well as the violation of Art. 2 of the European Convention, i.e. the right to life, arguing that the State had not taken appropriate measures to save the life of the applicant's children.

There is a practice of the ECtHR concerning the protection of the rights of the child and within the limits of recognizing the violation of the prohibition of slavery and servitude, which is enshrined in Art. 4 of the European Convention. According to the plot of the case Siliadin v. France (26 October, 2005), a fifteen-year-old Togolese citizen was brought by a French citizen to Paris and handed over to a married couple as a worker, which she was for several years. According to the author, this decision is indicative because it expresses the position of the ECtHR on the state of slavery in a broader sense. 
Thus, according to the ECtHR, the applicant had not been subjected to physical or mental violence, her case could be equated with forced labor, as she was a minor, was alone in a foreign country and could have been arrested for violating immigration rules, fearing spouses who at the same time promised to legalize her stay. Siliadi's enslavement was expressed in the fact that she was unable to choose a place of work and residence, had no means of subsistence and individual housing, had no freedom of movement, and was entirely dependent on B.'s spouses, who confiscated her passport. The ECtHR thus found a violation of Article 4 of the Convention for the Protection of Human Rights and Fundamental Freedoms, which guarantees freedom from slavery and forced or compulsory labor.

\section{Conclusions}

1. The practice of the ECtHR is recognized as a source of law in most states. And although the Ukrainian legal tradition does not recognize the status of judicial precedent as a source of law, such precedents are actively used in practice.

2. Decisions of the ECtHR are binding on States promoting the ideas set out in the European Convention and can be considered a common source of law for those countries, which certainly ensures a uniform interpretation of the rules on the protection of children's rights and brings their legal systems closer together.

3. The ECtHR considers a large number of applications that directly or indirectly concern children's rights. Thus, the ECtHR makes decisions within:

- the right to education (Article 2 of Protocol № 1 to the European Convention);

- freedom of conscience, the right to freedom of expression and freedom of association (Articles 9, 10, 11 of the European Convention);

- child abuse and neglect (Articles 3 and 8 of the European Convention);

- restriction of freedom of expression, receipt, and dissemination of information for health and morality (paragraph 2 of Article 10 of the European Convention);

- protection against discrimination (Article 14 of the European Convention), etc.

4. The above allegations should play a key role in national courts' decisions, as it is extremely difficult to identify completely identical 
Mykola Bondaruk, Serhiy H. Melenko, Liubov Omelchuk, Liliya Radchenko y Anzhela Levenets Juvenile Justitia and the protection of children's rights in Europe: the practice of the European Court of Human Rights

circumstances and legal relationships in respect of which a particular ECtHR decision has been made and to ascertain that it is appropriate to apply it. Thus, cases related to the rights and interests of minors are characterized by increased attention to detail, which determines their situation. It is for this reason that national courts should carefully rely on the ECtHR's decision-making practice.

5. The decision of the European Court of Human Rights is the basis for the formation, formation, and development of effective juvenile justice, which stands for the protection of children's rights.

6. Further research within the chosen topic should address the prospects of using the ECtHR's practice to protect the rights of the child for the development and establishment of the juvenile justice system in Ukraine, as well as the analysis of violations of children's rights by various European countries, to avoid similar violations by Ukraine in the future.

\section{Bibliographic References}

DZHUZHA, Anastasiia. 2013. "Prevention of crimes against sexual integrity of the child under the laws of other countries" In: Scientific Bulletin of the National Academy of Internal Affairs. Vol. 2, pp. 147-155.

EUROPEAN COURT OF HUMAN RIGHTS. 1979. Marckx v. Belgium, (Application no. 6833/74) 13 de junio de 1979. Avaliable online. In: http://hudoc.echr.coe.int/eng?i=001-57534. Consultation date: 05/02/2020.

EUROPEAN COURT OF HUMAN RIGHTS. 1998. A. v. The United Kingdom. (100/1997/884/1096) 23 September 1998. https://hudoc.echr.coe. int/fre\#\{\%22itemid\%22:[\%22001-58232\%22]\}. Consultation date: 05/02/2020.

EUROPEAN COURT OF HUMAN RIGHTS. 2003. Chamber judgment E. and Others v. United Kingdom. (Application no. 33218/96) 15 january 2003. Available online. In: http://hudoc.echr.coe.int/eng?i=001-60781. Consultation date: 05/02/2020.

EUROPEAN COURT OF HUMAN RIGHTS. 2004. ANDERSSON AND OTHERS v. SWEDEN. (Application no. 49297/99) 14 October 2004. Available online. In: http://hudoc.echr.coe.int/eng?i=001-67083. Consultation date: 05/02/2020.

EUROPEAN COURT OF HUMAN RIGHTS. 2004. Haase v. Germany. (Application no. 11057/02) 08 july 2004. Available online. In: http:// hudoc.echr.coe.int/eng?i=001-61704. Consultation date: 05/02/2020. 
EUROPEAN COURT OF HUMAN RIGHTS. 2005. Nachova v BULGARIA. (Applications nos. 43577/98 and 43579/98) 6 July 2005. Available online. In: http://hudoc.echr.coe.int/eng?i=001-69630. Consultation date: $05 / 02 / 2020$.

EUROPEAN COURT OF HUMAN RIGHTS. 2005. SILIADIN v. FRANCE. (Application no. 73316/o1) 26 october 2005. Available online. In: http:// hudoc.echr.coe.int/eng?i=001-69891. Consultation date: 05/02/2020.

EUROPEAN COURT OF HUMAN RIGHTS. 2006. HUNT v. UKRAINE. (Application no. 31111/o4) 7 march 2007. Available online. In: http:// hudoc.echr.coe.int/eng?i=001-78410. Consultation date: 05/02/2020.

EUROPEAN COURT OF HUMAN RIGHTS. 2007. FOLGERØ AND OTHERS v. NORWAY. (Application no. 15472/02) 29 June 2007. Available online. In: http://hudoc.echr.coe.int/eng?i=001-81356. Consultation date: $05 / 02 / 2020$.

EUROPEAN COURT OF HUMAN RIGHTS. 2007. KONTROVÁ v. SLOVAKIA. (Application no. 7510/04) 24 september 2007. Available online. In: http://hudoc.echr.coe.int/eng?i=001-80696. Consultation date: 05/02/2020.

EUROPEAN COURT OF HUMAN RIGHTS. 2008. HASAN AND EYLEM ZENGIN v. TURKEY. (Application no. 1448/04) 9 october 2007. Available online. In: http://hudoc.echr.coe.int/eng?i=001-82580. Consultation date: 05/02/2020.

EUROPEAN COURT OF HUMAN RIGHTS. 2009. Amanalachioai v. Romania. (Application no. 4.023/04) 26 may 2009. Available online. In: http:// hudoc.echr.coe.int/eng?i=001-122782. Consultation date: 05/02/2020.

EUROPEAN COURT OF HUMAN RIGHTS. 2009. KALACHEVA v. RUSSIA. (Application no. 3451/05) 7 august 2009. Available online. In: http:// hudoc.echr.coe.int/eng?i=001-92572. Consultation date: 05/02/2020.

EUROPEAN COURT OF HUMAN RIGHTS. 2009. SAVINY v. UKRAINE. (Application no. 39948/o6) 18 march 2009. Available online. In: http:// hudoc.echr.coe.int/eng?i=001-90360. Consultation date: 05/02/2020.

EUROPEAN COURT OF HUMAN RIGHTS. 2012. KAUTZOR v. GERMANY. (Application no. 23338/o9) 24 september 2012. Available online. In: http://hudoc.echr.coe.int/eng?i=001-109809. Consultation date: 05/02/2020.

EUROPEAN COURT OF HUMAN RIGHTS. 2017. M.S. v. UKRAINE. (Application no. 2091/13) 11 October 2017. Available online. In: https:// cutt.ly/cgk9fW8. Consultation date: 05/02/2020. 
Mykola Bondaruk, Serhiy H. Melenko, Liubov Omelchuk, Liliya Radchenko y Anzhela Levenets 184

Juvenile Justitia and the protection of children's rights in Europe: the practice of the European

EUROPEANCOURTOFHUMANRIGHTS. 2018.VYSHNYAKOVv.UKRAINE. (Application no. 25612/12) 24 october 2018. Available online. In: http:// hudoc.echr.coe.int/eng?i=001-184824. Consultation date: 05/02/2020.

KHARYTONOV, Evgen; KHARYTONOVA, Olena; KOSTRUBA, Anatolii; TKALYCH, Maksym; TOLMACHEVSKA Yuliia. 2021. "To the Peculiarities of Legal and Non-Legal Regulation of Social Relations in the Field of Sport" In: Retos. Vol. 41, pp. pp. 131-137.

KLIM, Serhii. 2014. "Procedural rights of the child in the context of decisions of the European Court of Human Rights" In: Scientific Bulletin of Kherson State University. In: Series: Legal Sciences. Vol. 4, No. 6-1, pp. 203-206.

KRESTOVSKAYA, Nataliia. 2008. Juvenile law of Ukraine: genesis and current state. Academia jurídica de Odessa. Odessa, Ukraine.

MAMYCH, Olena. 2012. The case law of the European Court of Human Rights on the protection of children from violence. In: International scientificpractical conference, pp. 480-491. Available online. In: http://dspace. onua.edu.ua/bitstream/handle/11300/9605/Mamich\%20480-491. pdf? sequence $=1$. Consultation date: 05/02/2020.

MENDZHUL, Mariia. 2020. Theoretical problems of the principles of family law. Kharkiv, Ukraine.

OPATSKY, Roman. 2012. "Juvenile policy: concept and content” In: Law and society. No. 1, pp. 37-40. Available online. In: http://pravoisuspilstvo. org.ua/2012/1_2012.pdf\#page=37. Consultation date: 15/02/2020.

PAVLICHENKO, Oleksandr; MARTYNENKO, Oleksii. 2017. Human rights in Ukraine. Ukrainian Helsinki Human Rights Union. Kyiv, Ukraine. Available online. In: https://helsinki.org.ua/wp-content/ uploads/2018/04/Preview_HumanRight2017-UKR-A46.pdf. Consultation date: $05 / 02 / 2020$.

PAVLOVA, Yuliia; POLUNINA, Olha; TKALYCH, Maxym; MANKOVSKYI, Volodymyr; ZUBAIR, Akhmad. 2020. "International-legal standards of cooperation of ukraine in the field of environmental (climate) problem" Amazonia Investiga. Vol. 9, No. 25, pp. 295-301.

SHYSHKA, Roman; TKALYCH, Maxym. 2020. "The World in 2020: What Are The Threats To Humanity?” In: Amazonia Investiga. Vol. 9, No. 26, pp. 3-5. Available online. In: https://amazoniainvestiga.info/index.php/ amazonia/article/view/1132. Consultation date: 15/02/2020.

TKALYCH, Maxym; SAFONCHYK, Oksana; TOLMACHEVSKA, Yuliia. 2020. "Private Law and human rights: New realities" In: DIXI. Vol. 32, pp. 1-12. 
LAW OF UKRAINE. 1997. Law 475/97-VR/1997 of July 30. On the Ratification of the Convention for the Protection of Human Rights and Fundamental Freedoms of 1950, the First Protocol and Protocols 2, 4, 7 and 11 to the Convention. Available online. In: https://zakon.rada.gov.ua/laws/ show/475/97-\%Do\%B2\%D1\%80\#Text. Consultation date:05/02/2020.

LAW OF UKRAINE. 2011. Order 1039-p /2011 of February 8. On approval of the plan of actions for implementation of the Concept of development of criminal justice concerning juveniles in Ukraine. Available online. In: https://zakon.rada.gov.ua/laws/show/1039-2011-\%D1\%80\#Text. Consultation date: $05 / 02 / 2020$.

LAWOFUKRAINE. Decree 597/2011 of May 24. On theConcept of Development of Criminal Justice for Juveniles in Ukraine. Available online. In: https:// zakon.rada.gov.ua/laws/show/597/2011\#Text. Consultation date: 05/02/2020.

LAW OF UKRAINE. Law 4651-VI/2012 of April 13, Criminal Procedure Code of Ukraine. Available online. In: https://zakon.rada.gov.ua/laws/ show/4651-17\#Text. Consultation date: 05/02/2020.

UNITED NATIONS. 1950. Convention for the Protection of Human Rights and Fundamental Freedoms. Available online. In: https://www.echr.coe.int/ documents/convention_eng.pdf. Consultation date: 05/02/2020.

UNITED NATIONS. 1989. Convention on the Rights of the Child. Available online. In: https://www.ohchr.org/en/professionalinterest/pages/crc. aspx?fbclid=IwAR35cVUouzhmgWieqVBgZYcB2BoAxOmowoWCMu4 zy7eIWfQD-VMAwGkORks. Consultation date: 05/02/2020.

VOLKOVA, Nataliia. 2018. "International legal protection of family rights and interests of the child by the European Court of Human Rights" In: Jurnalul Juridic National: teorie si practica. Vol. 1, No. 2. pp. 84-87. 

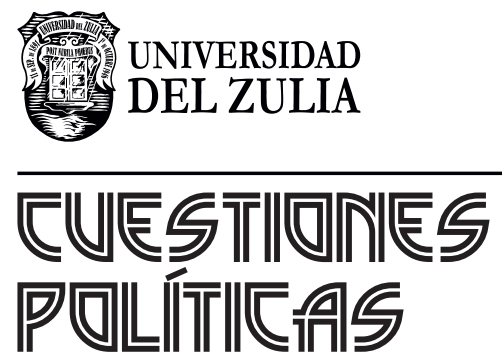

Vol.39 No 68

Esta revista fue editada en formato digital y publicada en enero de 2021, por el Fondo Editorial Serbiluz, Universidad del Zulia. Maracaibo-Venezuela 